\title{
Significance of serum c-erbB-2 oncoprotein, insulin-like growth factor-1 and vascular endothelial growth factor levels in ovarian cancer
}

\author{
Akcay T${ }^{1}$, Yasar $\mathrm{O}^{1}$, Kuseyri MA ${ }^{1}$, Dincer $\mathrm{Y}^{1}$, Aydinli $\mathrm{K}^{2}$, Benian $\mathrm{A}^{2}$, Balcan $\mathrm{E}^{2}$, Erenel $\mathrm{H}^{2}$ \\ Department of Biochemistry, Cerrahpasa Faculty of Medicine, 34303, Istanbul University, Istanbul, Turkey. \\ tulakcay@yahoo.com
}

\begin{abstract}
OBJECTIVES: Our aim was to determine the predictive values of serum levels of several growth factors in ovarian cancer, including soluble c-erbB-2 oncoprotein, insulin-like growth factor-1 (IGF-1) and vascular endothelial growth factor (VEGF).

BACKGROUND: Previous studies have shown that growth factors play an important role in carcinogenesis. METHODS: Two groups were established. One of them was the malignant group which included 41 patients with ovarian carcinoma and the other was the control group that was made up of 28 healthy volunteers. Preoperative serum samples were obtained from the patients, and c-erbB-2, IGF-1 and VEGF levels were measured in these samples using ELISA. Serum CA-125 levels were also determined, by chemiluminescent microparticle immunoassay. RESULTS: VEGF levels of the malignant group were significantly higher than those of the control group ( $p<$ $0.01)$. CA-125 levels were also significantly higher than the in control group $(p<0.001)$. Area under the ROC curve (AUC) was 0.982 for CA-125, 0.780 for VEGF, 0.603 for c-erbB-2, and 0.467 for IGF-1 in differentiating cancers from controls.

CONCLUSION: Serum VEGF levels might be a predictor for diagnosis in ovarian cancer patients, while serum c-erbB-2 and IGF-1 levels do not have a clinical significance in terms of ovarian cancer (Tab. 1, Fig. 1, Ref. 46). Text in PDF www.elis.sk.

KEY WORDS: c-erbB-2, insulin-like growth factor-1, vascular endothelial growth factor, CA-125, ovarian cancer.
\end{abstract}

\section{Introduction}

Cell proliferation has a major role in carcinogenesis. While many factors have an effect on this process, growth factors play the main role. Accumulation of permanent changes in the genes that code growth factors causes the cell to proliferate in an uncontrolled manner and consequently transform into tumor cells. Growth factors bind with the receptors on the surface of tumor cells from which they originate and thus trigger auto-stimulation, causing increased proliferation of tumor cells (1).

c-erbB-2 oncoprotein (also known as HER2/neu) is an analogue of epidermal growth factor (EGF) receptor. In bladder tumors, amplification and increased expression of the c-erbB-2 gene has been demonstrated through immunohistochemical technique, and it has also been determined that c-erbB-2 positivity correlates with histological grade (2-4).

${ }^{1}$ Department of Biochemistry, Cerrahpasa Faculty of Medicine, 34303, Istanbul University, Istanbul, Turkey, and ${ }^{2}$ Department of Gynecology and Obstetrics, Cerrahpasa Faculty of Medicine, 34303, Istanbul University, Istanbul, Turkey

Address for correspondence: T. Akcay, Fahrettin Kerim Gokay cd. No: 156/4, 34730, Kadikoy, Istanbul.

Phone: +90.542.2161359

Grant support: This study was supported by The Research Fund of Istanbul University (Project number: BYP-1910).
Insulin-like growth factor 1 (IGF-1) is a mitogenic, anti-apoptotic growth factor which causes the proliferation and differentiation of various cell types. High plasma IGF-1 levels have been shown to be associated with increased risk for prostate, lung, and colon cancer (5-7). In two studies investigating the serum levels of IGF 1 in bladder cancer patients, no significant difference was observed between the patient and control groups $(8,9)$.

Vascular endothelial growth factor (VEGF) is a mitogenic and angiogenic growth factor that increases vascular permeability. It is responsible for the growth and metastases of tumors. VEGF also increases the proliferation and migration of endothelial cells, and causes the degradation of extracellular matrix by activating urokinase, plasminogen activator and serin proteases (10).

The aim of this study was to determine the preoperative serum levels of c-erbB-2 oncoprotein, insulin-like growth factor 1 and vascular endothelial growth factor, compare these values to those of the control group, and discuss the clinical significance of these parameters.

\section{Materials and methods}

41 patients who were admitted to the Gynecology and Obstetrics Department at Cerrahpasa Faculty of Medicine and were diagnosed with ovarian cancer but did not receive any treatment 
prior to recruitment were included in the study. The exclusion criteria comprised pathologies related to growth hormone such as acromegaly, gigantism and dwarfism, thyroid function disorders, type I and II diabetes mellitus, and obesity. The control group was made up of 28 healthy volunteers with ages similar to those of the study group. The ethical committee of Istanbul University Cerrahpasa Faculty of Medicine approved this study, and informed consent was obtained from each participant.

For staging of ovarian cancer, the FIGO (International Federation of Gynecology and Obstetrics) system of classification was used. The postoperative histological analyses were carried out at the Department of Histopathology.

$10 \mathrm{~mL}$ of blood was drawn from each healthy volunteer and patient prior to surgery, then centrifuged and immediately stored at $-80{ }^{\circ} \mathrm{C}$ until analysis. Serum levels of c-erbB-2, IGF-1 and VEGF were determined using commercially available ELISA kits (Bender Med Systems Kit cat no: BMS 207 for c-erbB-2, Enzo Life Sciences Assay kit cat no: 900-150 for IGF-1, and Life Technologies cat no: KHG0111 for VEGF). CA-125 levels in serum were analyzed by chemiluminescent microparticle immunoassay (Roche Diagnostics cobas 6000 analyzer).

For interpretation of data, SPSS Statistics version 20 was utilized. Groups were first assessed by Kruskal-Wallis method, then pairwise comparisons were carried out by post-hoc Mann-Whitney U test with Bonferroni correction. For correlations, Spearman's rho was used.

\section{Results}

Histopathological examination of the patients، tumors identified their types as follows: 29 serous, 2 mucinous, 3 clear cell, 2 mixed, and 2 undifferentiated. Serum levels of c-erbB-2 oncoprotein, IGF-1, VEGF and CA-125 of the control group and the study group, sorted by the pathology data, are given in Table 1 .

Serum VEGF levels were significantly higher in the malignant group, compared to the control group $(\mathrm{p}<0.01)$. However, VEGF levels did not differ between early (stage I and II) and advanced (stage III and IV) stages. Both early and advanced stage groups demonstrated significantly higher VEGF levels compared to the control group ( $\mathrm{p}<0.05$ and $\mathrm{p}<0.01$, respectively).

CA-125 levels of the malignant group were significantly higher than those of the control group $(\mathrm{p}<0.001)$. In addition, they were

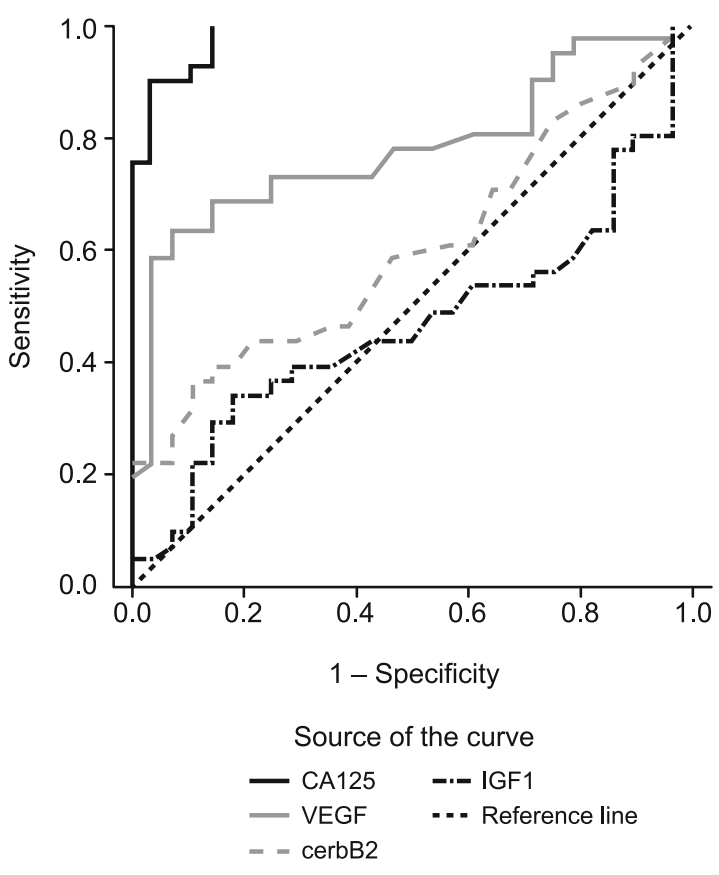

Fig. 1. Receiver operating characteristic curve for CA-125, vascular endothelial growth factor (VEGF), c-erbB-2, and insulin-like growth factor (IGF-1).

significantly higher in the advanced stage group, compared to the early stage group $(p<0.05)$. Both early and advanced stage groups had significantly higher CA-125 levels compared to the control group (both $\mathrm{p}<0.001$ ).

As shown in Figure 1, receiver operating characteristic (ROC) curve demonstrates that CA-125 performed best, followed by VEGF, c-erbB-2 and finally IGF-1. The area under the curve (AUC) was 0.982 for CA-125, 0.780 for VEGF, 0.603 for c-erbB-2, and 0.467 for IGF-1 in differentiating ovarian cancer patients from healthy controls. The cut-off points were determined to be $112 \mathrm{U} /$ $\mathrm{mL}$ for CA-125; $239 \mathrm{pg} / \mathrm{mL}$ for VEGF; $4.7 \mathrm{ng} / \mathrm{mL}$ for c-erbB-2; and $111 \mathrm{ng} / \mathrm{mL}$ for IGF-1. Using these values, the sensitivity vs. specificity were calculated for CA- 125 as $90 \%$ vs $96 \%$; for VEGF as $73 \%$ vs $75 \%$; for c-erbB-2 as $59 \%$ vs $54 \%$; and for IGF-1 as $44 \%$ vs $57 \%$.

Tab. 1. Serum levels of CA-125, vascular endothelial growth factor (VEGF), c-erbB-2 and insulin-like growth factor-1 (IGF-1) in controls and patients in different stages of disease.

\begin{tabular}{|c|c|c|c|c|c|c|c|c|c|c|c|c|}
\hline & \multicolumn{3}{|c|}{ CA-125 (U/mL) } & \multicolumn{3}{|c|}{ VEGF (pg/mL) } & \multicolumn{3}{|c|}{ c-erbB-2 (ng/mL) } & \multicolumn{3}{|c|}{ IGF-1 (ng/mL) } \\
\hline & mean & median & range & mean & median & range & mean & median & range & mean & median & range \\
\hline Control (n=28) & 31.21 & 26.3 & 97.6 & 226.86 & 213.5 & 563 & 4.88 & 4.6 & 5.8 & 112.28 & 108.5 & 283.96 \\
\hline $\begin{array}{l}\text { Early Stage } \\
\text { (I \& II) (n=21) }\end{array}$ & $328.71^{\mathrm{a}}$ & 200 & 953 & $411.48^{c}$ & 383 & 690 & 9.74 & 5.4 & 78.2 & 91.93 & 72 & 299.96 \\
\hline $\begin{array}{l}\text { Advanced Stage } \\
\text { (III \& IV) }(n=20)\end{array}$ & $1353.15^{\text {a.b }}$ & 386.5 & 8818 & $466.85^{d}$ & 570 & 705 & 5.33 & 4.8 & 11.8 & 132.06 & 124 & 323.6 \\
\hline $\begin{array}{l}\text { All Stages } \\
(\mathrm{I}-\mathrm{IV})(\mathrm{n}=41)\end{array}$ & $828.44^{\mathrm{a}}$ & 314 & 8845 & $438.49^{d}$ & 412 & 750 & 7.59 & 5 & 79.6 & 111.51 & 104 & 327.96 \\
\hline
\end{tabular}

${ }^{\mathrm{a}} \mathrm{p}<0.001$ - compared to the control group, ${ }^{\mathrm{b}} \mathrm{p}<0.05$ - compared to early stage group, ${ }^{\mathrm{c}} \mathrm{p}<0.05$ - compared to the control group, ${ }^{\mathrm{d}} \mathrm{p}<0.01-$ compared to the control group 
156-160

VEGF and CA-125 levels were each found to be correlated with disease stage (rho $=0.461, \mathrm{p}<0.01$; and rho $=0.846, \mathrm{p}<$ 0.01 , respectively). In addition, VEGF levels correlated with CA125 levels (rho $=0.378, \mathrm{p}<0.01$ ).

\section{Discussion}

Having the highest mortality rates among all gynecological cancers, ovarian cancer is more frequently seen in patients with family history or during postmenopause. Treatment options are usually limited because diagnosis often tends to be late (11). The identification of any pelvic mass as benign or malignant achieves certainty mostly after surgical intervention and pathological examination. This necessitates the development of a reliable method to provide early diagnosis for ovarian cancer. A variety of tumor markers are employed for the early diagnosis, guiding the treatment and spotting tumor recurrences of epithelial ovarian cancer.

CA-125, a glycoprotein with a high molecular weight, is secreted in various epithelial cancers by cells of coelomic epithelium (12). Serum levels of this protein have been found to be elevated in $80 \%$ of all epithelial ovarian tumors (13). However, elevated CA-125 levels were also found not only in advanced endometrial, fallopian tube and endocervical cancers (14), but also in non-gynecological cancers, such as breast, colon, pancreas and lung cancer $(14,15)$. In addition, non-malignant conditions may also cause elevated serum CA-125 levels as in endometriosis, pelvic inflammatory disease, gestation and menstruation (16-18). Despite these limitations, CA-125 is an important tool in monitoring the follow-up of patients diagnosed with ovarian cancer $(19,20)$. Currently available tumor markers mostly possess low sensitivity and specificity. Their tendency to raise during non-malignant conditions further limits their diagnostic usefulness. Therefore, additional tumor markers should be investigated in serum.

Being one of the best predictive markers, c-erbB-2 determines those patients who are likely to respond to anti-c-erbB-2 (trastuzumab) therapy. Thus, in year 2000, the American Society of Clinical Oncology (ASCO) recommended the measurement of c-erbB-2 levels in every breast cancer patient for its predictive value despite the lack of sufficient data to use it as a prognostic factor. Furthermore, there have been many studies investigating the expression of c-erbB-2 in tissues of lung, gastric, breast and colorectal cancer, although the results are contradictory (21-27). The serum levels and tissue overexpression of c-erbB-2 were found to be correlated in ovarian cancer (28). While there are studies arguing that c-erbB-2 should not be used as a prognostic factor despite having determined that its tissue expression levels correlate with disease stage (29), there are also studies which suggest its use as a diagnostic serum marker even though they haven't found any significant difference in its levels between stage, grade or histological types (30). It has also been reported that serum c-erbB-2 levels may not be related to CA-125 levels, but can still reflect its expression levels in tissue (31). In one of their studies, Meden $\mathrm{H}$ et al (32) first reported an increase of c-erbB-2 in ovarian cancer; however, they argued in a following study that it possessed limited clinical significance (33). Our findings support the latter study (33) on this controversial issue.

IGF-1 has strong mitogenic and anti-apoptotic effects on cells $(34,35)$. It has been demonstrated that all IGF-peptide binding proteins are present in both normal and malignant ovarian epithelial cells (36), and that overexpression of IGF-1 receptors plays a role in the malignant transformation of these cells (37). While it has been suggested in a study with 47 patients with ovarian cancer (24 benign and 23 malignant) that low IGF-1 levels may be used as a reliable marker to separate benign tumors from malignant ones (38), it has also been recently reported that serum levels of IGF-1 neither were significantly different between the malignant group or healthy controls nor correlated with clinical findings, histological grade or response to chemotherapy although the majority (90\%) of patients were in advanced stage in another study which included 50 patients (39). Similarly, we found no significant difference between the study group and the controls.

VEGF is a potent mitogenic factor through its effects on mitogenesis, angiogenesis, endothelial lifespan and hematopoesis (40). The first studies investigating the relationship between the prognosis of ovarian cancer and VEGF levels (40-42) found that those patients with elevated levels had worse prognosis. Another study argued that serum VEGF levels are insufficient for distinguishing benign and malignant ovarian lesions (43), while another reported that increased levels were related to reduced lifespan among invasive carcinoma group and that VEGF levels were significantly higher in invasive carcinoma compared to low-malignant and benign groups (44). Also, one study found elevated VEGF levels in ovarian cancer patients compared to healthy women and that these levels were significantly higher in advanced than in early stage ovarian cancer, suggesting VEGF as a new potential tumor marker for ovarian cancer (45). On the other hand, there are studies which indicate that preoperative serum VEGF levels are not correlated with CA-125 levels, but can be used as an independent risk factor for prognosis (46). In our study, VEGF levels were elevated both in early and advanced stage patients and these levels correlated with CA-125 levels, therefore our findings support the study by Cooper BC et al (44).

In conclusion, we suggest that VEGF could be a useful biomarker in combination with CA-125 for the diagnosis of ovarian cancer, however serum IGF-1 and c-erbB2 levels seem limited for this purpose.

\section{References}

1. Mendelsohn J. Neoplastic Diseases. In: Wilson JD, Braunwald E, Isselbacher KJ, Petersdorf RG, Martin JB, Fauci AS, Root RK, editors. Harrison's Principles of Internal Medicine. 12th ed. McGraw-Hill, Inc. New York. p. 1579.

2. Ohta M, Konno H, Tanaka T et al. The significance of circulating vascular endothelial growth factor (VEGF) protein in gastric cancer. Cancer Lett 2003; 192: 215-225. 
3. Lönn U, Lönn S, Friberg S, Nilsson B, Silfverswärd C, Stenkvist B. Prognostic value of amplification of c-erb-B2 in bladder carcinoma. Clin Cancer Res 1995; 1: 1189-1194.

4. Vollmer RT, Humphrey PA, Swanson PE, Wick MR, Hudson ML. Invasion of the bladder by transitional cell carcinoma: its relation to histologic grade and expression of p53, MIB-1, c-erb B-2, epidermal growth factor receptor, and bcl-2. Cancer 1998; 82: 715-723.

5. Aly MS, Khaled HM. Detection of C-erb B2 gene amplification in bilharzial associated bladder cancer using fluorescence in situ hybridization. Urol Oncol 2004; 22: 448-452.

6. Chan JM, Stampfer MJ, Giovannucci E et al. Plasma insulin-like growth factor-I and prostate cancer risk: a prospective study. Science 1998; 279: 563-566.

7. Ma J, Pollak MN, Giovannucci E et al. Prospective study of colorectal cancer risk in men and plasma levels of insulin-like growth factor (IGF)-I and IGF-binding protein-3. J Natl Cancer Inst. 1999; 91: 620-625.

8. Yu H, Spitz MR, Mistry J, Gu J, Hong WK, Wu X. Plasma levels of insulin-like growth factor-I and lung cancer risk: a case-control analysis. J Natl Cancer Inst. 1999; 91: 151-156.

9. Serel TA, Turan T, Soyupek S, Aybek Z, Perk H. Urine and serum free IGF-1 levels in patients with bladder cancer: a brief report. Urol Res 2003; 31: 297-299.

10. Shariat SF, Kim J, Nguyen C, Wheeler TM, Lerner SP, Slawin KM. Correlation of preoperative levels of IGF-I and IGFBP-3 with pathologic parameters and clinical outcome in patients with bladder cancer. Urology 2003; 61: 359-364.

11. Pecorelli S, Benedet JL, Creasman WT, Shepherd JH. FIGO staging of gynecologic cancer. 1994-1997 FIGO Committee on Gynecologic Oncology. International Federation of Gynecology and Obstetrics. Int J Gynaecol Obstet 1999; 65: 243-249.

12. Kabawat SE, Bast RC Jr, Bhan AK, Welch WR, Knapp RC, Colvin RB. Tissue distribution of a coelomic-epithelium-related antigen recognized by the monoclonal antibody OC125. Int J Gynecol Pathol 1983; 2: 275-285.

13. Bast RC Jr, Klug TL, St John $\mathbf{E}$ et al. A radioimmunoassay using a monoclonal antibody to monitor the course of epithelial ovarian cancer. N Engl J Med 1983; 309: 883-887.

14. Niloff JM, Klug TL, Schaetzl E, Zurawski VR Jr, Knapp RC, Bast RC Jr. Elevation of serum CA125 in carcinomas of the fallopian tube, endometrium, and endocervix. Am J Obstet Gynecol 1984; 148: 1057-1058.

15. Kawahara M, Terasaki PI, Chia D, Johnson C, Hermes M, Tokita K. Use of four monoclonal antibodies to detect tumor markers. Cancer 1986; 58: 2008-2012.

16. Barbieri RL, Niloff JM, Bast RC Jr, Scaetzl E, Kistner RW, Knapp RC. Elevated serum concentrations of CA-125 in patients with advanced endometriosis. Fertil Steril 1986; 45: 630-634.

17. Halila H, Stenman UH, Seppälä M. Ovarian cancer antigen CA 125 levels in pelvic inflammatory disease and pregnancy. Cancer 1986; 57: 1327-1329.

18. Pittaway DE, Fayez JA. Serum CA-125 antigen levels increase during menses. Am J Obstet Gynecol 1987; 156: 75-76.

19. Coussy F, Chéreau E, Daraï E et al. Interest of CA 125 level in management of ovarian cancer (article in French with an abstract in English). Gynecol Obstet Fertil 2011; 39: 296-301.
20. Maggino T, Gadducci A. Serum markers as prognostic factors in epithelial ovarian cancer: an overview. Eur J Gynaecol Oncol 2000; 21: 64-69.

21. Osaki T, Mitsudomi T, Oyama T, Nakanishi R, Yasumoto K. Serum level and tissue expression of c-erbB-2 protein in lung adenocarcinoma. Chest 1995; 108: 157-162.

22. Kono K, Naganuma H, Sekikawa T et al. Serum level of HER-2/neu in patients with gastric cancer: correlation with HER-2/neu overexpression in gastric carcinoma tissue. Tumour Biol 2000; 21: 139-144.

23. Andersen TI, Paus E, Nesland JM, McKenzie SJ, Børresen AL. Detection of c-erbB-2 related protein in sera from breast cancer patients. Relationship to ERBB2 gene amplification and c-erbB-2 protein overexpression in tumour. Acta Oncol 1995; 34: 499-504.

24. Molina R, Jo J, Filella $X$ et al. C-erbB-2 oncoprotein in the sera and tissue of patients with breast cancer. Utility in prognosis. Anticancer Res 1996; 16: 2295-2300.

25. Fontana X, Ferrari P, Namer M, Peysson R, Salanon C, Bussiere F. C-erb-B2 gene amplification and serum level of c-erb-B2 oncoprotein at primary breast cancer diagnosis. Anticancer Res 1994; 14: 2099-2104.

26. Arnaout AH, Dawson PM, Soomro $S$ et al. HER2 (c-erbB-2) oncoprotein expression in colorectal adenocarcinoma: an immunohistological study using three different antibodies. J Clin Pathol 1992; 45: 726-727.

27. Essapen S, Thomas H, Green M et al. The expression and prognostic significance of HER-2 in colorectal cancer and its relationship with clinicopathological parameters. Int J Oncol 2004; 24: 241-248.

28. Felip E, Encabo G, Vidal MT, Vera R, del Campo JM, Rubio D. C-erbB-2 protein in ovarian epithelial cancer: correlation between expression in tumor tissue and blood levels (article in Spanish with an abstract in English). Med Clin (Barc) 1995; 105: 5-8.

29. Frutuoso C, Silva MR, Amaral N, Martins I, De Oliveira C, De Oliveira HM. Prognosis value of p53, C-erB-2 and Ki67 proteins in ovarian carcinoma (article in Portuguese with an abstract in English). Acta Med Port 2001; 14: 277-283.

30. Balcan E, Demirkiran F, Aydin Y et al. Serum levels of epidermal growth factor, transforming growth factor, and c-erbB2 in ovarian cancer. Int J Gynecol Cancer 2012; 22: 1138-1142.

31. McKenzie SJ, DeSombre KA, Bast BS et al. Serum levels of HER-2 neu (C-erbB-2) correlate with overexpression of p185neu in human ovarian cancer. Cancer 1993; 71: 3942-3946.

32. Meden H, Marx D, Fattahi A et al. Elevated serum levels of a cerbB-2 oncogene product in ovarian cancer patients and in pregnancy. $\mathrm{J}$ Cancer Res Clin Oncol 1994; 120: 378-381.

33. Meden H, Marx D, Schauer A, Wuttke W, Kuhn W. Prognostic significance of p105 (c-erbB-2 HER2/neu) serum levels in patients with ovarian cancer. Anticancer Res 1997; 17: 757-760.

34. Khandwala HM, McCutcheon IE, Flyvbjerg A, Friend KE. The effects of insulin-like growth factors on tumorigenesis and neoplastic growth. Endocr Rev 2000; 21: 215-244.

35. Larsson O, Girnita A, Girnita L. Role of insulin-like growth factor 1 receptor signalling in cancer. Br J Cancer 2005; 92: 2097-2101.

36. Lukanova A, Kaaks R. Endogenous hormones and ovarian cancer: epidemiology and current hypotheses. Cancer Epidemiol Biomarkers Prev 2005; 14: 98-107.

37. Coppola D, Saunders B, Fu L, Mao W, Nicosia SV. The insulin-like growth factor 1 receptor induces transformation and tumorigenicity of 


\section{6-160}

ovarian mesothelial cells and down-regulates their Fas-receptor expression. Cancer Res 1999; 59: 3264-3270.

38. Serin IS, Tanriverdi F, Yilmaz MO, Ozcelik B, Unluhizarci K. Serum insulin-like growth factor (IGF)-I, IGF binding protein (IGFBP)-3, leptin concentrations and insulin resistance in benign and malignant epithelial ovarian tumors in postmenopausal women. Gynecol Endocrinol 2008; 24: $117-121$.

39. Tas F, Karabulut S, Serilmez M, Ciftci R, Duranyildiz D. Clinical significance of serum insulin-like growth factor-1 (IGF-1) and insulinlike growth factor binding protein-3 (IGFBP-3) in patients with epithelial ovarian cancer. Tumour Biol 2014; 35: 3125-3132.

40. Delli Carpini J, Karam AK, Montgomery L. Vascular endothelial growth factor and its relationship to the prognosis and treatment of breast, ovarian, and cervical cancer. Angiogenesis 2010; 13: 43-58.

41. Paley PJ, Staskus KA, Gebhard K et al. Vascular endothelial growth factor expression in early stage ovarian carcinoma. Cancer 1997; 80: 98-106.
42. Tempfer C, Obermair A, Hefler L, Haeusler G, Gitsch G, Kainz C. Vascular endothelial growth factor serum concentrations in ovarian cancer. Obstet Gynecol 1998; 92: 360-363.

43. Obermair A, Tempfer C, Hefler $L$ et al. Concentration of vascular endothelial growth factor (VEGF) in the serum of patients with suspected ovarian cancer. Br J Cancer 1998; 77: 1870-1874.

44. Cooper BC, Ritchie JM, Broghammer CL et al. Preoperative serum vascular endothelial growth factor levels: significance in ovarian cancer. Clin Cancer Res 2002; 8: 3193-3197.

45. Peng XP, Li JD, Li MD, Ye XM, Yan WC. Clinical significance of vascular endothelial growth factor in sera of patients with gynaecological malignant tumors (article in Chinese with an abstract in English). Ai Zheng 2002; 21: 181-185.

46. Tan XJ, Lang JH, Shen K, Wang L, Wu M, Xu XY. Correlation of preoperative serum vascular endothelial growth factor level with CA125 level in patients with epithelial ovarian cancer and its prognostic value (article in Chinese with an abstract in English). Zhonghua Fu Chan Ke Za Zhi 2008; 43: 9-12. 